\title{
Who cares about financialization? Self-reinforcing feedback, issue salience, and increasing acquiescence to market-enabling takeover rules
}

\section{Helen Callaghan* \\ *Correspondence: hc@mpifg.de}

Max Planck Institute for the Study of Societies, Cologne, Germany

\begin{abstract}
Financialization requires a regulatory framework that allows markets to emerge and expand. What explains growing political acquiescence to relevant market-enabling rules? The present article identifies feedback processes whereby such rules lock in over time. First, as markets expand, market proponents grow more numerous and develop increasing stakes. Second, potential challengers find it increasingly difficult to mobilize protest, because routinization reduces salience and because market exposure renders protesters more vulnerable. Third, potential challengers lose incentives to protest, because market exposure eliminates some non-market structures that inspire defensive action, and because 'constrain-thy-neighbor' dynamics encourage the further spread of market-enabling rules as a means of self-defense. The case of market-enabling takeover regulation in Britain since the 1950s illustrates how these processes gradually changed the preferences and resources of bankers, institutional investors, corporate managers and employees and thereby help explain why parliamentary interest in market-restraining counter-measures grew weaker over time.
\end{abstract}

Key words: Political economy, comparative politics, historical institutionalism, United Kingdom, corporate governance, institutional change, capitalist development

JEL classification: P16 political economy, N24 economic history, K22 regulation and business law

\section{Introduction}

Financialization, defined broadly as the 'increasing role of financial motives, markets, actors and institutions' (Epstein, 2005, p. 3) in many spheres of social life requires a regulatory framework that allow markets to emerge and expand. The distributional consequences of relevant market-enabling rules manifest themselves not just during crises. But during the decade

(C) The Author 2015. Published by Oxford University Press and the Society for the Advancement of Socio-Economics. All rights reserved. For Permissions, please email: journals.permissions@oup.com 
preceding the Great Recession, they incurred hardly any protest. In liberal and coordinated market economies alike, even left-of-center governments introduced reforms conducive to financial sector expansion (Cioffi and Höpner, 2006).

Previous research on financialization largely neglects this political dimension. Scholarly attention has centered on the economic or socio-cultural consequences of the turn to finance, including its relationship to macroeconomic performance and stability, income inequality, workplace organization or the diffusion of financial concepts, languages and evaluative practices beyond the economic realm (for reviews, see Engelen and Konings, 2010; Deutschmann, 2011; Lapavitsas, 2011; van der Zwan, 2014). Those interested in causes have largely focused on actors or forces that actively propel financialization. A prominent example is Streeck's (2009) account of capitalist development, which identifies unruly profit-seeking opportunists as the main drivers of institutional change in capitalist social systems. But even state-centered accounts emphasize the role of the state in the creation of financial markets though pension reform, privatization, deregulation and the like (see van der Zwan, 2014, pp. 116-17). The macroeconomic constraints highlighted by Krippner (2011) and others help explain government choices but do not fully account for the weak opposition. To understand the dynamics of financialization, we need to know not just why market-enabling rules were promoted but why politicians of all political stripes increasingly acquiesced.

The literature on issue salience addresses one ingredient of acquiescence-namely, low public attention-but so far, it has little to say about change over time. Culpepper (2011), for example, compares salience across issues but neglects long-term intertemporal variation. Other scholars have highlighted the importance of crises or focal events, and some have shown how interest groups and political entrepreneurs strategically seek to influence salience (see Oppermann and de Vries, 2011; Pagliari, 2013, pp. 91-101), but what affects the likelihood of crises or actors' inclination to manipulate salience is not typically explored. The nascent literature on how 'policy makes mass politics' does take an interest in such questions, yet up to now, it has focused mainly on the effects of social welfare programs on recipients' propensity to mobilize (see Campbell, 2012, pp. 340-41).

My explanation of increasing acquiescence to the regulatory bases of financialization highlights the self-reinforcing effects of market-enabling rules. The effects of regulatory choices on the subsequent dynamics of policy conflict are the subject of a large and growing literature on endogenous institutional change (see Jacobs and Weaver, 2014). Early accounts of pathdependent processes focused on self-reinforcing processes, whereby policies bolster their own bases of political support (e.g. Pierson, 1993, 1994; Skocpol, 1995). More recently, interest has also extended to self-undermining processes, whereby policies engender growing opposition or enhance the resources of those inclined to challenge them (e.g. Streeck and Thelen, 2005; Mahoney and Thelen, 2010; Jacobs and Weaver, 2014). One interesting aspect of the following case study is the weakness of self-undermining effects.

In Britain since the 1950s, several feedback mechanisms fostered growing acquiescence to market-enabling takeover rules. First, much like the welfare state programmes studied by Pierson, Skocpol and others, market-enabling takeover rules nurtured their own support base. Beneficiaries gained relative political weight, in terms of both numbers and resources, through proliferation, migration, conversion or side payments. Second, protest became more difficult with the spread of market-enabling rules: regulatory routinization lowered issue salience by reducing the likelihood of headline-grabbing scandals; growing exposure to market pressure enhanced the penalties for resisting further marketization. Third, even 
without penalties or side payments, marketization weakened-rather than strengthened-potential challengers' motivation to resist: elimination of stakeholder-oriented companies (through market-induced exposure to takeover threats) removed tangible incentives for resistance by leaving victims with less to fight for; 'constrain-thy-neighbor' incentives encouraged victims to spread market-enabling rules and thereby divert the takeover threat onto an expanded pool of targets; the possibility of takeover bids by companies with more committed owners may have nurtured paradoxical hopes in the market as savior from market forces.

By highlighting these mechanisms, the present article complements ongoing research on the dynamics of capitalist development. Streeck (2011), Sewell (2008), Boyer (2011) and others have recently revived a classical strand of research in political economy by asking whether capitalism has distinct 'laws of motion.' Systematic analysis of feedback effects helps determine whether and why gradual institutional change in contemporary capitalism proceeds predominantly in the direction of liberalization (see Streeck and Thelen, 2005, pp. 30-33; Streeck, 2009, p. 240).

The article proceeds as follows. Section 2 justifies the focus on takeover rules in Britain since the 1950s and summarizes relevant regulatory developments. Section 3 documents the decline in party political opposition. Section 3 explains growing acquiescence by documenting changes in the preferences of key interest groups and relates them to the processes just outlined. The final section engages with the literatures on endogenous change, issue salience and capitalist development. It concludes with suggestions for further research.

\section{The evolution of takeover rules as an example of marketization processes}

Financialization means many different things to a growing community of scholars. Apart from Epstein's broad definition, Krippner's (2011, p. 4) more narrow focus on the 'tendency of profit making . . . to occur increasingly through . . . financial channels rather than productive activities' is also widely used. The latter definition may be more conducive to cumulative comparative research efforts, because it is more easily quantifiable, and helps delineate financialization proper from its causes and from its consequences (cf. Nölke, 2014).

On both definitions, takeover bids contribute to financialization because they encourage treatment of the corporation as a bundle of assets to be evaluated, eliminated or acquired on the exclusive basis of financial returns. Takeover bids are public tender offers addressed directly to shareholders, bypassing the managerial board of the target company. Where they are frequent, it is common to speak of an active market for corporate control. Unlike merger proposals, cash bids require neither the evaluation of complex alternative business plans, nor managerial consent (cf. Pound, 1993, pp. 1019-20). Shareholders confronted with them need only assess who is offering the highest value for their shares. The evaluation of company performance thus reduces to easily measurable financial criteria. As Lin and Devey put it, this transition to the 'finance conception of the firm' (Fligstein, 1993) 'prepared the episteme and the techne to engage in financial activities for nonfinance firms' (Lin and Tomaskovic-Devey, 2013, p. 1292).

The present article focuses on takeover regulation not because of such causal links between active markets for corporate control and other aspects of financialization. Instead, it starts with the assumption that financialization depends on marketization, defined as the creation of 'regulatory preconditions for markets to arise and develop, thereby extending the market 
mechanism to new areas of social life (Apeldoorn and Horn, 2007, p. 215). On this assumption, insights regarding the political dynamics of marketization processes contribute to explaining financialization. The gradual evolution of political attitudes to market-enabling takeover rules in Britain since the 1950s serves as an illustrative example to highlight lock-in mechanisms that may also apply to other market-enabling rules, including other rules pertaining to financialization.

Markets for corporate control do not arise spontaneously even where share ownership is widely dispersed. Although takeover bids ultimately depend on the actions of private individuals, public rules and public policies can encourage or prevent them. Bidders cannot obtain control without the incumbent directors' consent unless the board of the target company owns, or represents, fewer than $50 \%$ of the voting rights attached to shares. Where rules permit shares with unequal voting rights, founding families and incumbent directors frequently issue such shares to forestall hostile bids. Even where voting rights are equal and widely dispersed, the cards remain stacked against potential bidders. The managers of target companies command asymmetric information and decision-making powers delegated to them by shareholders. Rules designed to activate the market for corporate control remove these strategic advantages.

The distributional consequences are difficult to measure with any degree of accuracy (see White, 2012, p. 798n51), but they are widely believed to be substantial. An influential strand of economic theory presents the marketization of corporate control as an effective means of forcing managers to maximize 'shareholder value'. The simple theory has many caveats and some major flaws (see von Thadden, 1990; Cook and Deakin, 1999). These flaws help explain why empirical evidence does not support claims that takeovers improve the operative performance of target companies (Mueller, 2012, p. 428). However, although causal attribution is difficult, companies in the UK and the USA, where takeover bids are most frequent, do pay out a higher proportion of their earnings in dividends and a lower proportion in wages than do companies in countries with less active markets for corporate control (de Jong, 1996; Streeck and Höpner, 2003, p. 25; see also Pendleton and Gospel, 2005). Moreover, hostile takeovers tend to involve more significant reductions in employment than do negotiated mergers (White, 2012, p. 802).

Given these distributional consequences, it is worth asking why political resistance to market-enabling takeover rules has declined in many advanced industrialized democracies. Takeover regulation once provoked intense struggles between the advocates of shareholderand stakeholder-oriented varieties of capitalism. At the European Union level, a directive aimed at facilitating takeover bids encountered stiff resistance for 30 years before a watereddown version passed in 2003 (Callaghan, 2006). At the national level, many advanced industrialized countries, including Germany and Japan, abstained from promoting marketization until the 1990s. In the UK, where the first unsolicited tender offer succeeded in 1953, takeover bids featured in the opening paragraph of the Labour Party's 1959 election manifesto. Historically, governments intent on curbing the practice also passed company laws to strengthen managerial defenses, constrained bidders' access to finance, exercised their veto rights or used tax incentives to render takeovers less lucrative. In recent years, such marketrestraining measures have gone out of fashion and are demanded less and less, even by opposition parties. $^{1}$

1 Foreign takeovers are a partial exception. See Callaghan $(2013,2015)$. 
In Britain, marketization has gone further than anywhere else, including the USA (see Armour and Skeel, 2007; Armour et al., 2011). The 1948 Company Act reduced the informational asymmetries that had previously prevented hostile bids by introducing more stringent accounting standards and disclosure requirements (see Cheffins, 2003, pp. 20-21). In 1959, responding to a spate of bids, the Bank of England convened a working group of city practioners, who drew up the Notes on Amalgamations. The Notes' four main guidelines stated that there should be no interference with the free market in shares; that shareholders themselves should decide whether to sell; that they deserved access to all relevant information and that they should be given time to digest it (Armour et al., 2011, p. 236). In 1969, a similarly composed working group replaced the Notes with the Takeover Code, which was more specific, but no less share-holder oriented. As summarized by Armour and Skeel (2007, p. 1760),

it consisted of a series of ten general principles, instantiated in 35 specific rules. . . . The basic principle of shareholder choice . . . was now supplemented by a general ban on frustrating actions, and specific prohibitions of transactions likely to induce this-issuing shares, disposing of material assets or entering into a significant contract- without the approval of shareholders. Similarly specific requirements were set out in relation to the equal treatment of shareholders.

Several further amendments followed, but the strongly market-enabling character of code remained untouched for several decades. The 1985 Company Act incorporated many of the Code's provisions, and they were retained in the 2006 Company Act, which also gave the Takeover Code a statutory basis (Patrone, 2011, p. 67). It was not until 2011 that the so-called Cadbury Law placed some new constraints on bidders (see Kirchfeld and Matthew, 2013; Higgins and Thexton, 2014).

It is precisely because of its exceptionalism that the British case lends itself well to a longitudital analysis of attitudes toward marketization. Elsewhere takeover bids emerged later and remain less common, partly due to greater concentration of corporate ownership (see Jackson and Miyajima, 2008). As a result, Culpepper's (2011) otherwise impressive comparative study regarding the issue salience of takeover regulation in France, Germany, Japan and the Netherlands suffers from the problem that the markets for corporate control in all four countries are relatively new and weakly developed. Where there are no bids, the absence of protest is hardly surprising, and in the space of 10 years, there is limited variation to be observed.

Despite its exceptionalism, the processes dicussed below travel beyond the British case. They apply elsewhere to the extent that previously inactive national takeover markets in Continental Europe and in developing countries are moving toward greater marketization of corporate control. There were strong signs of this prior to the financial crisis (e.g. Höpner and Jackson, 2006; Armour et al., 2011). If and where marketization fails to advance, the feedback effects of market-restraining rules are a worthy topic for future comparative research.

The following section summarizes the evolution of party political resistance to the marketization of corporate control in the UK, based on parliamentary debates and policy choices between 1953 and 2010.

\section{Mapping the decline in parliamentary opposition}

Takeover bids proceed in waves. Precise figures are not available for the 1950s, but Johnston (1980, pp. 9-10) notes intense takeover activity in 1953 and 1954 and again in the late 1950s. Well-documented waves peaked-in terms of numbers-in 1968, 1971, 1986 and 1999. Of 


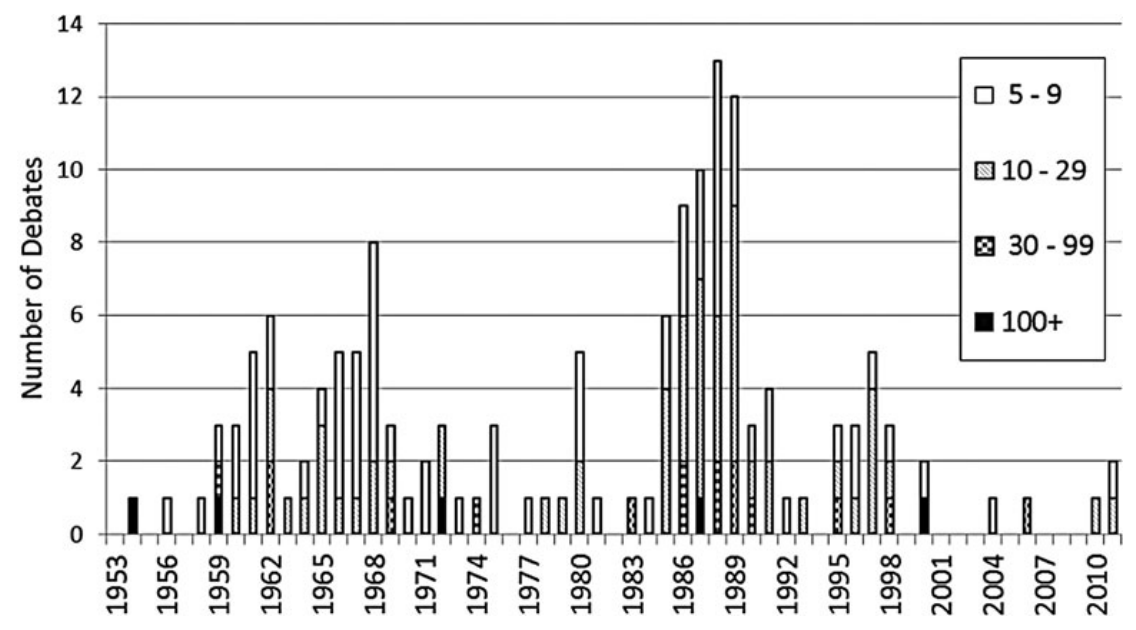

Figure 1. Number of Commons debates in which the term 'takeover' or 'take-over' is mentioned at least $x$ times.

Source: Author's count based on Hansard (1953-2005) and Hansard (2006-2010).

these, the third wave, during the late 1980s, was by far the largest in terms of value. At its peak in terms of value in 1989, the average deal value (at 1990 prices) was $£ 20$ million, that is, 10 times larger than in 1968 or 1972 (Sudarsanam, 2003, p. 24). Bids were more aggressive than before, partly because Big Bang deregulation had opened the city of London to US investment banks that had brought their takeover expertise (Sudarsanam, 2003, p. 25). The fourth wave, during the 1990s, was largely fuelled by the privatization and deregulation of many sectors, including water, electricity, gas and telecoms.

Political attention to the issue correlates strongly with the number of bids. Figure 1 maps the distribution of relevant parliamentary debates ${ }^{2}$ in the British House of Commons between 1953 and 2010. The cyclicality shows that takeover regulation is too abstract to elicit sustained political attention. Parliamentarians, like the general public, require tangible reminders of why the marketization of corporate control needs to be addressed.

Beyond that, the distribution of debates also indicates a decline in attention that is suggestive of a decline in resistance. Since 1998, issues related to takeover bids featured on average in less than one debate a year, in other words, less than during any comparable stretch of time during the 60-year history of the phenomenon. Less attention suggests weaker resistance because intense debates take place only where issues are controversial.

2 The debates, recorded in Hansard, were sourced from Millbank Systems (http://hansard. millbanksystems.com) (for debates prior to 2006) and from the website of the UK Parliament (http:// www.parliament.uk/business/publications/hansard) (for debates from 2006 to 2010). The complete data set contains all debates in which the phrase 'takeover bid' or 'take-over bid' occurs at least once. Within that set of 582 documents, 150 texts feature at least 5 occurrences of the term 'takeover' or 'take-over' and 21 texts feature at least 30 occurrences. In five of them, the search terms occur more than 100 times. Debates featuring fewer than five occurrences are excluded from the diagram because the reference to takeover bids, if relevant at all, is too fleeting. 
The content of the debates ${ }^{3}$ corroborates the impression of declining resistance. The following summary inevitably omits nuances and much of the political and economic context that influenced both tone and content. Broadly speaking, early debates featured strong opposition to active markets for corporate control, including vocal calls for market-restraining measures. Over time, opposition grew weaker and moved to the back benches. Front-bench MPs became more reluctant to condemn contested takeovers and more willing to endorse the removal of barriers to active markets for corporate control.

In 1954, during the first major debate on the subject, takeover bidding was problematized not just by Labour delegates but also by leading Conservatives, including R. A. Butler, chancellor of the Exchequer. ${ }^{4}$ In 1959, in the context of hostile bids for British Aluminium and Watney Man, only two Conservative MPs spoke up against takeovers, but this reluctance was due at least partly to strong party discipline in the run-up to the 1959 general election. The Financial Times suspected that on a free vote, the motion condemning hostile bids, tabled by the Labour opposition, would have been carried by a majority of two to one (Wincott, 1959). Those Conservatives who defied the whip spoke passionately of 'a danger that the industrialist class is being superseded by the financier-accountant class ${ }^{3}$ and condemned institutional investors 'more interested in an immediate good price for the benefit of their policy holders...than in the long-term future of an industrial venture'. ${ }^{6}$ In later years, Conservatives complaining about takeovers mainly worried about their effects on competition. ${ }^{7}$ Those who denounced asset stripping or short-termism were mostly confronted with opposed bids in their own constituencies at the time of the debates. ${ }^{8}$ Foreign bids provoked stronger protest, including in the 1980s (see Callaghan, 2009, pp. 748-749), but even with regard to them, calls for intervention receded over time (see Callaghan and Hees, 2013).

The same applies to government action. Roberts describes how, in 1953, Winston Churchill's outrage at a hostile bid for the Savoy prompted political intervention.

After consulting with the Governor of the Bank of England (BoE), . . . the Treasury relied on the BoE [to help cut bidders off from credit]. . . Bids did not cease, but most likely they were fewer in number and smaller in scale than would otherwise have been the case. (Roberts, 1992, pp. 189-91)

3 I used MaxQDA10 to code the five most intense debates on the subject (i.e. featuring more than 100 mentions of the term 'takeover'), all of which took place at times of high takeover activity: February 11, 1954: Commons debate 'Takeover bids'; June 29, 1959: Commons debate 'The Condition of Private Industry'; November 11, 1972: Commons debate 'Takeovers and Mergers'; January 28, 1987: Commons debate 'The City and Industry'; June 6, 2000: Commons debate 'Market Abuse'. In addition, I also read and partially coded all debates featuring more than five mentions of the term 'takeover'.

4 R. A. Butler, Conservative, Saffron Walden, Commons Hansard 1954-02-11, col. 1458; see also Sir Walter Fletcher, Conservative, Bury and Radcliffe, Commons Hansard 1954-02-11, col. 1422; John Bennett, Conservative, Reading, North, Commons Hansard 1954-02-11, col. 1434.

5 William Shepherd, Conservative, Cheadle, Commons Hansard 1959-06-29, col. 89.

6 Geoffrey Stevens, Conservative, Portsmouth Langstone, Commons Hansard 1959-06-29, col. 105.

7 Anthony Grant, Conservative, Harrow Central, Commons Hansard 1972-11-24, col. 1825; Paul Channon, Conservative, Secretary of State for Trade and Industry, Commons Hansard 1987-01-28, col. 373; Michael Grylls, Conservative, Surrey-North-West, Commons Hansard 1987-01-28, col. 399.

8 Janet Fookes, Conservative, Merton and Morden, Commons Hansard 1972-11-24, col. 1777; Bill Walker, Conservative, Tayside North, Commons Hansard 1987-01-28, col. 421. An exception was Sir Peter Holdern, Conservative, Horsham, Commons Hansard 1987-01-28, col. 384. 
In late 1958 and early 1959, the battle for British Aluminium 'was discussed several times in Cabinet and it took up a considerable amount of the time of the Prime Minister, Harold Macmillan'. Ministers came under pressure to intervene by strategically using the government's power to withold capital issue and foreign exchange consents. However, the Cabinet was less worried about the conduct of bids than about the future of the British aluminum industry. By this criterion the hostile bidder-British-American consortium Reynolds/ $\mathrm{TI}$-was preferred to the white knight, the Aluminum Company of America (Alcoa), 'mainly because legal control would remain in British hands'. The government therefore decided to let the hostile takeover go ahead (Roberts, 1992, p. 192).

For the subsequent five decades, Conservative governments consistently remained passive. In November 1959, following Labour Party demands for a statutory body to regulate takeovers and continuing criticism of government policy, Macmillan appointed the Jenkins Committee. However, the committee 'was given a limited mandate: they were to consider the duties of directors and the rights of shareholders in the event of a bid, but broader questions of social and economic policy were excluded . . . [and] many of the recommendations of the Jenkins Committee as regards takeovers were not implemented in legislation (Johnston, 2007, pp. 432-34). Under Thatcher, the 1984 Tebbit Doctrine-named after her secretary for trade and industry-relinquished the main instrument of intervention available to British governments by announcing that henceforth takeovers would no longer be referred to the Monopolies and Mergers Commission on any grounds other than concern about significant adverse effects on competition. During the years that followed, the government resisted pressure to prevent foreign takeovers of British 'crown jewels' including British Leyland, Pilkington and Rowntree (Riddell, 1988b). After Thatcher's departure, a change in Conservative rhetoric was not matched by significant policy change. An all-party parliamentary select committee recommended wide-ranging changes to takeover law in 1991 and again in 1994, but these were not implemented (Bowen, 1994). Instead, the Major government relied on private coordination to address the problem of short-termism. It rejected tax breaks for long-term shareholdings in favor of attempts to improve communication between managers and investors (Leadbeater, 1990). In the same spirit, the 1995 Myners Report Developing a Winning Partnership 'described what institutional investors should do but did nothing to ensure they would do so' (Howard, 2005, p. 180; cf. Callaghan, 2009, p. 749).

The attitudes of Labour MPs changed later and more abruptly. In 1954, Party Leader Hugh Gaitskell, Roy Jenkins and others complained at length about takeover bids. ${ }^{9}$ Major concerns included assett stripping, bidders' large tax free profits, and the detrimental effects of takeover threats on the dividend restraint policy imposed on companies as part of the post-war reconstruction efforts. During the 1959 election campaign, amidst controversial bids for for British Aluminium and the brewery Watney Man, the future prime minister Harold Wilson led a heated debate on the subject (see Callaghan 2009). Party Chairman Tony Benn and others were equally passionate in 1972. In the run-up to the 1987 general election, which again coincided with intense takeover activity, the future party leader John Smith and many others reitereated Labour's longstanding complaint that Conserative Governments 'simply leave it to the shareholders and let the devil take the hindmost. ${ }^{10}$ In 1988 , the future

9 For example, Hugh Gaitskell, Labour, Leeds South, Commons Hansard 1954-02-11, col. 1438-48; Roy Jenkins, Labour, Birmingham, Commons Hansard 1954-02-11, col. 1383-93.

10 John Smith, Labour, Monklands East, Commons Hansard 1987-01-28, col. 364. 
prime minister Tony Blair questioned 'whether 30 or 40 fund managers [were] the right people to decide the future of key industrial sectors' (Riddell, 1988a). From 1991 onward, the Labour Party toned down its confrontational rhetoric. Mo Mowlam, Labour's spokeswoman for industry, announced that 'the natural antagonism between the City and Labour ha[d] now passed, ' but that industry was 'pig-sick' of its vulnerability to predators (Dawnay, 1991). In 1995-96, Labour elites still mounted critiques of shareholder value norms, promoting 'stakeholder capitalism' instead (see Kelly et al., 1997).

Demands of Labour in opposition included incorporating the Takeover Code and Takeover Panel into a statutory framework of city regulation; asking companies to prove that industrial or commercial gains would come from a proposed merger; replacing the Tebbit Doctrine, which made competition the main test for barring takeovers, with other public interest tests; lowering the threshold triggering mandatory bids; ensuring employee consultation on takeovers; and changing the tax treatment of share ownership to produce a bias in favor of long-term holdings (see Callaghan, 2006, pp. 78-79).

Labour's stance changed shortly before Tony Blair's 1997 election victory. In February 1997, a commission established by the left-leaning Institute of Public Policy Research pronounced that 'there should be no new administrative restraints on takeovers' (Wagstyl and Rice, 1997). The three Labour governments that followed faithfully stuck to this advice. In June 2000, Stephen Byers, trade and industry spokesman, told a conference organized by the Trades Union Congress (TUC) that reforms intended to make companies pay more attention to stakeholders were not on the government's agenda (Taylor, 2000). In May 2001, Blair's 'business manifesto' promised reforms to facilitate takeovers (Maguire, 2001). In the run-up to the 2010 election, in the context of a controversial bid for Cadbury, Gordon Brown and Peter Mandelson repeated over and over again that governments must not interfere with shareholders' right to decide.

\section{Feedback effects of market-enabling rules}

What explains growing acquiescence to market-enabling takeover rules? My answer relies on the assumption that parties cater to their clienteles, and that with regard to technical issues like takeover regulation, interest groups carry particular weight. The following section argues that feedback mechanisms triggered by the rules themselves contributed to changing the demands of relevant groups. They did so in three ways: by boosting the numbers, stakes and/or resources of market beneficiaries; by reducing challengers' capacity to draw attention to the issue; and by weakening challengers' incentives to protest.

\subsection{Increase in the number, stakes and/or politically relevant resources of beneficiaries}

Beneficiaries of active markets for corporate control include minority shareholders, investment banks, 'raiders' (i.e. entrepreneurs specializing in hostile bids), and managers with 'golden parachutes'. All these groups gained political weight, in terms of numbers and resources, through proliferation, migration, conversion or side payments.

Institutional investors with minority stakes in many companies emerged and grew alongside market-enabling rules. The percentage of shares owned by pension funds grew from $1 \%$ in 1957 to $17 \%$ in 1975 and $31 \%$ in 1991 . The percentage of shares owned by insurance companies grew from $8 \%$ in 1957 to $16 \%$ in 1975 and 20\% in 1991 (Cheffins and Bank, 2007, 
p. 802). The numeric increase in institutional investors was caused in part by the same tax rules that drove large blockholders to divest their stakes and thereby rendered takeover bids attractive during the 1950s (Cheffins and Bank, 2007). Institutional investors continued to prosper in Britain's active and increasingly well-regulated market for corporate control at least partly because as minority shareholders they benefited from the strong minority shareholder protections (see La Porta et al., 2000) enforced by the Takeover Panel and from the substantial takeover premiums that accrue to target firm shareholders. Pension fund managers and other institutional investors have fiduciary duties to maximize shareholder returns in the interest of their members. They also depend on the liquidity generated by active markets for corporate control to realize capital gains and meet short-term performance targets (see Jackson and Vitols, 2001, pp. 175, 185-87). Conversely, the 'herd mentality' of fund managers may contribute to fuelling takeover waves (see Jackson and Vitols, 2001, p. 186).

Investment banks adapted their business models to the new profit opportunities associated with active markets for corporate control, thereby swelling the ranks of market supporters. When hostile bids first occurred in the 1950s, established merchant banks still had reason to fear that their involvement with hostile bids would elicit punishment by other members of what at the time was still a tight, club-like business network. When in 1959 the merchant banks Warburgs, Hellberg, Waggs and Schroders violated unwritten rules by financing a hostile bid for British Aluminium, the banks advising the target company 'were outraged and appalled [and were backed in their protest by] . . . a 'City Consortium', comprising 14 of the most respected names in the Square Mile' (Roberts, 1992, p. 192).

When the government and the Bank of England refrained from intervening, the bankers underwent a conversion that fits Culpepper's (2005) description of a 'joint belief shift'. According to Roberts (1992, p. 193), 'the humiliation of the City Consortium changed City attitudes to take-overs overnight and henceforth financial advisors added hostile bids to their repertoire of merger and acquisition techniques'. After Big Bang deregulation in the 1980s, London's lucrative investment banking business also attracted many entrants from abroad (see Augar, 2008). According to Davies et al., UK banking sector assets rose from around $30 \%$ of GDP in 1960 to just over $100 \%$ in $1975,200 \%$ in $1985,300 \%$ in 2000 and more than 500\% in 2008 (Davies et al., 2010, p. 325, chart 7).

Professional raiders also developed growing stakes in Britain's market for corporate control. Jim Slater, chairman of Slater Walker Securities, who specialized in asset stripping takeovers during the 1960s, 'initially had few buyout rivals, but due to its notoriety and popularity with investors, various other companies began imitating its business plan of buying companies and reshaping the assets to generate a profit' (Cheffins, 2008, p. 365). During the 1980s, aggressive acquisitive conglomerates included Hanson Trust, BTR (formerly British Tyre and Rubber), Tomkins and Williams Holdings and others. By the end of the 1980s, '[Hanson's] annual pre-tax profits surpassed $£ 1$ billion and the company was valued at more than $£ 8.6$ billion, placing it third out of all FTSE 100 companies by gain in market value during the decade' (Cheffins, 2008, p. 367).

Corporate managers' growing acquiescence is attributable to a combination of conversion and side payments. During the first wave of hostile bids, managers regularly denounced 'raiders' as 'speculators' intent on the 'predatory dismembering' of British businesses (see Armour and Skeel, 2007, pp. 1772, 1775). They felt within their rights to defend themselves by whatever means they pleased and frequently did so (see Johnston, 1980). By the late 1960s, 'management opposition to the idea of hostile takeovers had waned dramatically' (Armour 
and Skeel, 2007, p. 1775), because some managers had converted to the practice of hostile bids: 'Starting in the 1960s, bids were driven by consolidation, and managers were just as likely to be bidders as targets in this milieu' (Armour and Skeel, 2007, p. 1775). Although the resulting divisions within the managerial community did not quell all protest, they weakened the capacity of managerial associations to speak with one voice.

Compensatory side payments may help explain why, since the late 1980s, divisions within the Confederation of British Industry (CBI) have all but disappeared. 'Golden handshakes' or golden parachutes that guarantee generous compensation in the event of takeover-related job loss effectively insulate managers from the disciplinary pressures of the market for corporate control. They could thus be interpreted as a bribe that buys managerial acquiescence. As Boyer (2005, p. 21) puts it, 'beneath the tyranny of investors, an implicit alliance between managers and investors takes place'.

Systematic historical data on severance pay arrangements are not available and golden handshakes are not new. As early as 1954, Labour leader Hugh Gaitskell complained that 'the directors of the original companies are in a position to bargain so as to take care of their own position . . . as a rule, the crucial point in such negotiations . . . is whether directors threatened with displacement feel that they will be adequately looked after.' (Commons Hansard 1954-02-11, col. 1443) The first use of the phrase 'golden handshake' in a Commons debate dates back to 1959 (Harold Wilson, Labour, Commons Hansard 1959-06-29, col. 41). Between 1959 and 1989 it was used regularly in takeover-related debates, appearing 59 times in 22 debates. ${ }^{11}$

Neverthless, there is reason to suspect that golden handshakes became more widespread in response to the takeover boom of the 1980s-a period that also saw dramatic change in other dimensions of British executive pay. Stock options became popular after 1984 and the gap between top pay and manufacturing operatives increased dramatically as a result. In FTSE 100 firms, the top-to-bottom pay differentials increased from 9:1 in 1978/79 to 54:1 in 2002/3 (see also Conyon and Schwalbach, 2000, p. 507; Erturk et al., 2005, p. 54). According to a 1993 Incomes Data Survey, 'the typical severance arrangement for a senior executive with a three-year rolling contract was two years' pay plus compensation for the loss of any expected bonus' (Thompson, 2005, p. 22n4). Labour Research reported that in 1992, '48 directors of UK listed companies had received severance pay in excess of $£ 100$ 000 . . Eleven of these directors had pay offs exceeding $£ 500000$ ' (Conyon, 1994, p. 26). From the early 1990s onward, a backlash against excessive severance payments has led to their partial curtailment (Thompson, 2005, p. 22ff), but compensation still takes place.

\subsection{Mounting difficulty and cost of protest}

Apart from boosting pro-market clienteles, market-enabling rules also made it more difficult for potential challengers to draw attention to their cause. Two mechanisms were at work.

First, regulatory routinization lowered issue salience by reducing the likelihood of headlinegrabbing scandals. When takeovers first appeared in the United Kingdom, there was no regulatory framework for their conduct and the resulting scandals provoked the anger of a broad and diverse coalition that extended beyond those directly affected. By 1959, according to the Financial Times, 'the average person . . . [was] so offended by the trappings of some bids and mergers that he tend[ed] to be sickened by the whole process' (Wincott, 1959). The fact that

11 Strangely, there are no further mentions after 1989. 
the first bidders were unruly entrepreneurs willing to violate unwritten norms added an element of drama that journalists were happy to exploit: 'In the popular press, where take-overs received plentiful attention in the 1950 s, they were portrayed as swashbuckling duels whose "distinctive flavour" was the regular trouncing of the Establishment by buccaneer outsiders' (Roberts, 1992, p. 186). Over time, as the regulatory framework matured, bids became more mainstream, scandals grew fewer, and media interest declined.

A rough ${ }^{12}$ indicator of declining news coverage stems from The Times Digital Archive (http://find.galegroup.com/ttda), which offers full text coverage from 1775 through 2006 and allows searches by news item category. The results presented in Figure 2 are based on an advanced search for all items containing the term 'takeover bids' ${ }^{13}$ or 'take-over bids' in the sub-categories 'News/News' or 'Business/Business and Finance'. Whereas the number ${ }^{14}$ of articles in the business and finance section of the newspaper correlates with the number of bids, the number of articles in the news section clearly declines over time. General news coverage peaked in 1959, exceeding subsequent coverage even during the takeover boom periods of the late 1960s, early 1970s, late 1980s and mid-1990s. A content analysis of relevant articles in The Times or an extension of the news item count to other newspapers would produce more robust results, but both are beyond the scope of the present article. For the USA, Hirsch (1986, pp. 813-26) shows that the linguistic framing of takeover bids grew more market-endorsing over time.

The relevance of media attention for political attention is emphasized by Culpepper (2011) and, more generally, by a large literature on issue salience. That it is not the only determinant is obvious from a comparison between Figures 1 and 2. Unlike news coverage in The Times, the number of parliamentary debates peaked in the late 1980s, and political attention from 1995 to 1997 also exceeded media attention. Slow adaptation to trends in salience and to changing interest group preferences may have contributed to the Labour party's multiple election defeats prior to programmatic reform.

More noteworthy in the present context is the salience pattern itself. Culpepper's focus on the period from 1996 to 2007 leads him to classify the issue salience of takeover regulation as inherently low. My longer term perspective suggests that salience curves are hump-shaped instead. At low levels of marketization, salience is low due to the absence of bids. As the number of bids increases, salience rises, but only at first. Over time, actors adjust and salience declines. A rigorous cross-country comparative test of this hypothesis exceeds the scope of the present article but would be worth conducting.

Market-enabling rules contributed to the decline in salience simply by virtue of being rules. The practitioners responsible for drawing up the 1969 Takeover Code appreciated this

12 Note that the results reported here include no information regarding the length, content or page placement of the articles in question. They are also likely to depend on search terms and may vary across newspapers.

13 The plural was used to exclude articles that reported only one bid, without discussing the broader phenomenon.

14 The ratio of articles on takeover bids to the overall number of articles in each section per year displays a stronger trend in the same direction, because the overall number of articles in each section almost doubled over time, from around 17,000 to around 30,000 a year in the news section, and from around 6,000 to around 12,000 a year in the business section. I report absolute numbers instead of ratios because they are easier to interpret. 


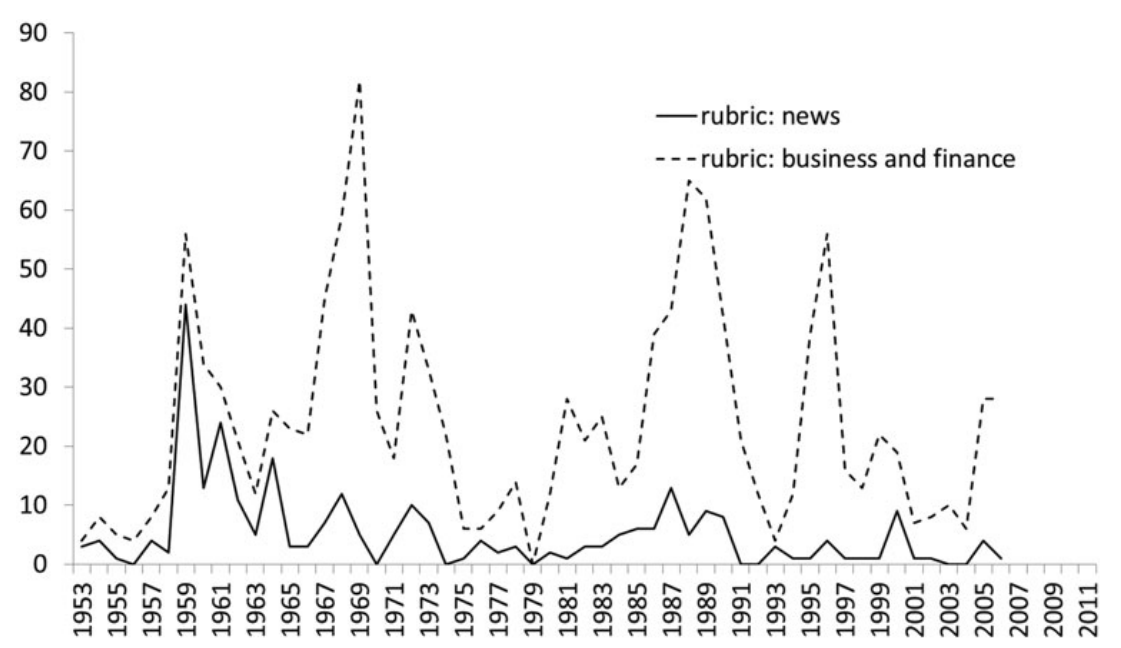

Figure 2. Annual number of articles on takeover bids in The Times, 1953-2006.

Source: Author's count, based on The Times Digital Archive (1785-2006).

effect: 'This is our last chance before legislation', one of them remarked in view of strong media pressure for the government to intervene (cited in Johnston, 1980, p. 41). In 1971, the Chair of the Takeover Panel expressed satisfaction that the panel had been 'rather less "in the news" during the past year: a welcome circumstance... also resulting from a general acceptance of the Panel's activity as part of the normal machinery of the City' (Panel on Takeovers and Mergers 1969-2010, p. 3). A further effect of marketization was the growing callousness of those not directly affected by takeovers. 'By the summer of 1959 The Times was commenting that in recent weeks there had been such a flow of take-over bids that, if the trend continued, bids would cease to be news' (Johnston, 1980, p. 18).

Second, market-enabling rules enhance the market-admistered penalties for attempts to contravene them. Managers exposed to strong so-called shareholder value pressure can less easily afford to complain the stronger the shareholders' exit options, because mobile shareholders can punish lack of commitment to high dividends with an immediate drop in the share price. The same applies to defensive measures. When hostile bids first arose in the UK, many company boards responded by implementing unequal voting rights, pyramids and strategic cross-shareholding. Franks et al. (2005, pp. 584-85) describe how

within a period of fifteen years about 7.5 per cent of listed companies had issued dual-class shares with discriminatory voting rights. In others, they sought protection under the wing of a friendly parent. In particular, in the brewing industry, Whitbread provided protection through large stakes to several local brewers under what became known as 'the Whitbread umbrella.

The same authors attribute the subsequent elimination of these structures to the growing dominance of institutional investors:

Financial institutions had become steadily more influential investors in equities by the 1950 s and 1960s, and with the agreement of the stock exchanges they were able to deny these firms access to 
the capital markets. The result was the dismantling of the protective measures until they were virtually extinguished by the 1980s. (Franks, et al., 2005, pp. 584-85)

Some claim that market-administered penalties for resistance also apply to workers. In 2010, Senior Tory MP Bill Wiggin accused workers protesting against the Cadbury takeover of putting their own jobs at risk 'by sending out such negative signals'. He expressed doubts on whether anyone would want 'to hire a whingeing workforce when you can have a positive upbeat one' (Walker and Griffin, 2010).

\subsection{Weakening incentives to protest?}

Effects of market-enabling rules on potential challengers' motivation to protest are difficult to prove. Nevertheless, three such effects may have contributed to the decline in resistance which, from the mid-1990s onward, extended to the Labour Party.

First, to the extent that takeover threats force companies to prioritize shareholder value, expanding markets for corporate control gradually eliminate stakeholder-oriented companies, thus leaving market opponents with less to fight for. Caution is always in order when interpreting declared motivations, because they may strategically mask the genuine motives (see Frieden, 1999). However, the desire to preserve a company's stakeholder orientation is a plausible reason for objecting to bids. In the 1950s, when stakeholder-oriented companies were presumably more numerous than today, it was regularly advanced by politicians. In 1954, Roy Jenkins and others explained Labour's reservations by noting that

at least the very big public companies exist for a great number of reasons other than that of making profits for their shareholders. The importance of the whole take-over bid situation is that it is a direct challenge to that understanding. ${ }^{15}$

In later years, bids for three particularly stakeholder-oriented companies-Pilkington (1986), Rowntree (1987) and Cadbury (2010)—sparked unusually intense debates (Callaghan, 2015). In all three cases, managerial paternalism was advanced as a reason to mobilize against the bid (see Callaghan, 2015, p. 18)-albeit with decreasing success. Commenting on the weakness of protest against the 2003 takeover of Pilkington, David Watts (Labour), the MP representing the constituency where Pilkington had its headquarters, observed that, '[nowadays] large companies like Pilkington are mainly controlled by London-based investors anyway and therefore the local link isn't as strong as it might have been in the past' (McDonough, 2005). In the same vein, Cadbury chairman Roger Carr dismissed nostalgic sentiments regarding the Kraft takeover by pointing out that '[Cadbury's] hadn't been a family company for 50 years, it hadn't had a member of the family working in it for a decade. Fifty per cent of the company was purchased from an American drug company-it simply wasn't the business people believed it to be' (Wiggins, 2010).

Second, as the marketization of corporate control contributes to the expansion of highly lucrative financial services, it becomes more difficult for politicians to ignore bankers' and investors' demands. This applies forcefully to the UK, where banking sector assets rose from around $30 \%$ of GDP in 1960 to just over $100 \%$ in $1975,200 \%$ in $1985,300 \%$ in 2000 and more than 500\% in 2008 (Davies et al., 2010, p. 325, chart 7). In 2007, financial services

15 Roy Jenkins in Commons Hansard 1954-02-11, col. 1393; see also John Strachey, Labour, Commons Hansard 1954-02-11 col. 1420 and Eric Fletcher, Labour, Commons Hansard 1954-02-11, col. 1430. 
accounted for $4 \%$ of total UK employment, $15 \%$ of income tax and $26.5 \%$ of corporation tax (Morgan, 2012, p. 379). London in 2005 had 328000 jobs in financial services, with the three largest subsectors - equities and bonds trading, professional services and investment banking - each employing more than 50000 people. According to estimates cited by Folkman et al. (2007), this amounted to $41 \%$ of all the 'city-type' financial services in the European Union.

Third, constrain-thy-neighbor incentives led potential challengers to support the territorial spread of market-enabling rules as a means of self-defense (see Callaghan, 2011). In the late 1980s, deep divisions on the issue of British takeover regulation did not prevent the CBI from strongly endorsing an EU directive that would facilitate takeover bids in other EU member states. As an internal memo explained, 'the aim [was] to reduce the UK's relative vulnerability by removing barriers elsewhere' (CBI, 1989). In the years preceeding the Single Market, many US companies were trying to acquire a foothold in the European Union, and British companies were their main targets. John Banham, CBI director general, complained that in most Continental countries, hostile bids have as much chance of succeeding as a snowball in Hades, so the acquirers of companies within the Community in the run-in to $1992 \ldots$. have no option but to buy in Britain' (Brewerton, 1989). Some British managers hoped that if the EU removed takeover barriers elsewhere, US companies would start targeting French and German companies and leave British ones alone.

Fourth, and most tentatively, I submit that some potential challengers welcome the possibility of takeover bids by companies with more committed owners as a way to reduce exposure to stock market pressure. Assessing this hypothesis rigorously would require interviews or survey evidence. Casual evidence includes the striking inclination of spokesmen for the TUC to endorse foreign takeovers. In 2006, Ian Brinkley, the TUC's chief economist, declared that 'foreign deals are often better for British workers' (Hotten and Conway, 2006). In 2009, Tim Page, the TUC's senior policy officer, said that 'foreign owners can be better than British ones, if they invest and expand the business' (Wachman, 2009). Conversely, Conservatives endorsed political intervention where takeovers threatened to result in 'imported socialism' or 'nationalisation by the back door'. ${ }^{16}$ To this end the 'Lilley Doctrine', named after John Major's secretary for trade and industry, pronounced in July 1990 that takeovers by state-run enterprises would henceforth be vetted by the Monopolies and Mergers Commission (Seely, 2014, pp. 6-8).

\section{Conclusion}

In sum, the present article explains growing acquiescence to the marketization of corporate control in Britain since the 1950s by highlighting the self-reinforcing feedback effects of market-enabling takeover rules. Marketization influenced the subsequent dynamics of policy conflict by changing the preferences and resources of relevant groups. Several processes were at work. First, market proponents grew more numerous and developed increasing stakes as a result of market expansion. Second, potential challengers found it increasingly difficult to mobilize protest, because issue salience declined after the implementation of rules and because market-enabling rules enhance the capacity of market forces to penalize those who attempt to contravene them. Third, and paradoxically, increasing marketization may have weakened 
rather than strengthened potential challengers' motivation to protest, because it left them with less to fight for; because constrain-thy-neighbor incentives encourage the spread of marketenabling rules as a means of self-defense; and possibly because the ownership concentration that results from some takeovers potentially reduces market exposure.

By identifying self-reinforcing processes that defused the protest, the article helps explain why the self-undermining processes explored by recent research on endogenous change did not shape political conflict in the case at hand. Market-enabling arrangements endured not only because beneficiaries grew stronger. Marketization also engendered decreasing opposition. Importantly, this decrease did not exclusively reflect potential challengers' growing satisfaction with the marketized status quo. The reduction in blatantly abusive bidding behavior did contribute to a decline in salience, but employees still had something to fight against: the distributional consequences of exposure to bids persist after regulatory routinization. However, with the gradual elimination of stakeholder-oriented companies, there were fewer tangible assets left to defend.

The analytic focus on feedback effects could fruitfully be extended to other policies and rules that are equally relevant to financialization. One example is the effect of pension reform on voters' financial market participation. The shift from public to private pensions and from defined-benefit plans to defined-contribution plans increasingly link household interests to the stock market. Whether the 'split identities' (Boyer, 2010, p. 350) of capital-owning workers encourage acquiescence to financialization is still unclear. On the one hand, growing equity stakes may render workers more supportive of policy measures and corporate decisions conducive to maximizing the financial return on these assets (see Gourevitch and Shinn, 2005, pp. 208-28). On the other hand, van der Zwan (2011) and McCarthy (2014) show that some union-controlled investment funds in Germany, Canada and the USA experiment with shareholder activism to advance better employment conditions, with varying degrees of success. Either way, pension policies shape the subsequent dynamics of policy conflict regarding other aspects of financialization. The example of pension reform also serves as a reminder that the marketization of corporate control does not take place in a political vacuum. The processes identified here are part of a larger and more complicated picture.

Importantly, my account is not deterministic. Positive feedback processes suggest only that the metaphorical window of political opportunity for market-taming measures narrows over time, not that it ever closes completely. Marketization is not irreversible, although bigger scandals and large crises may be needed to trigger market-restraining counter-moves, the longer marketization endures. Recent amendments to the UK's Takeover Code are consistent with this argument. The 2011 Cadbury Law responded to the public outrage sparked when Kraft revoked a promise not to close plants, less than a week after acquiring Britain's wellloved chocolate maker. The 2008 financial crisis and accession of the reform-minded Liberal Party to coalition government power were also conducive to the amendments. As is often the case in political science, context cannot fully be controlled for, and it matters a lot (see Hall, 2010).

Whether similar feedback processes apply across different types of capitalism requires further research. The present study focuses exclusively on the effects of market-enabling rules once such rules were put in place. However, market-restraining rules also nurture their own clienteles. In the case of takeover regulation, these clienteles include large blockholders and creditors that are no less resourceful or opportunistic than the beneficiaries of 
marketization. Systematic comparison of the feedback mechanisms triggered by different types of rules would shed additional light on the dynamic relationship between between politics and financial markets.

\section{Acknowledgements}

I thank Pepper Culpepper, David Dequech, Peter Gourevitch, Niamh Hardiman, Benjamin Werner, Andreas Nölke, Gregory Jackson, Basak Kus, Gunnar Trumbull and the anonymous reviewers for helpful comments on earlier versions of this article.

\section{References}

Apeldoorn, B. v. and Horn, L. (2007) 'The Marketization of European Corporate Control: A Critical Political Economy Perspective', New Political Economy, 12, 211-235.

Armour, J. and Skeel, D. (2007) 'Who Writes the Rules for Hostile Takeovers, and Why? The Peculiar Divergence of U.S. And U.K. Takeover Regulation', Georgetown Law Journal, 95, 1727-1794.

Armour, J., Jacobs, J. B. and Milhaupt, C. (2011) 'The Evolution of Hostile Takeover Regimes in Developed and Emerging Markets', Harvard International Law Journal, 52, 221-285.

Augar, P. (2008) The Death of Gentlemanly Capitalism: The Rise and Fall of London's Investment Banks, London, Penguin.

Bowen, D. (1994, April 29) 'Committee Seeks Controls on Hostile Takeovers', The Independent, London, p. 29.

Boyer, R. (2005) 'From Shareholder Value to CEO Power: The Paradox of the 1990s', Competition and Change, 9, 7-47.

Boyer, R. (2010) 'The Collapse of Finance but Labour Remains Weak', Socio-Economic Review, 2, 348-353.

Boyer, R. (2011) 'Are There Laws of Motion of Capitalism?', Socio-Economic Review, 9, 59-81.

Brewerton, D. (1989, March 23) 'Mopping up Britain for a Couple of Nabiscos', The Times, London, p. 27.

Callaghan, H. (2006) European Integration and the Clash of Capitalisms- British, French and German Disagreements over Corporate Governance, 1970-2003, Ph.D. thesis, Northwestern University.

Callaghan, H. (2009) 'Insiders, Outsiders and the Politics of Corporate Governance: How Ownership Structure Affects Party Positions in Britain, Germany and France', Comparative Political Studies, 42, 733-762.

Callaghan, H. (2011) 'Constrain-Thy-Neighbor Effects as a Determinant of Transnational Interest Group Cohesion', Comparative Political Studies, 44, 910-931.

Callaghan, H. (2015) 'Something Left to Lose? Network Preservation as a Motive for Protectionist Responses to Foreign Takeovers', Review of International Political Economy, 22.

Callaghan, H. and Hees, A. (2013) 'Wirtschaftsnationalismus im Wandel der Zeit: Der politische Diskurs um ausländische Unternehmensübernahmen in Großbritannien seit den 1950erJahren', MPIfG Discussion Paper 13/14, Cologne, Max Planck Institute for the Study of Societies.

Campbell, A. (2012) 'Policy Makes Mass Politics', Annual Review of Political Science, 15, 333-351. CBI (1989) CBI Memorandum: Contested Takeovers- the International Dimension, London, CBI. Cheffins, B. R. (2003) 'Law as Bedrock: The Foundations of an Economy Dominated by Widely Held Public Companies', Oxford Journal of Legal Studies, 23, 1-23.

Cheffins, B. (2008) Corporate Ownership and Control_British Business Transformed, Oxford, Oxford University Press. 
Cheffins, B. and Bank, S. (2007) 'Corporate Ownership and Control in the UK: The Tax Dimension', Modern Law Review, 70, 778-811.

Cioffi, J. and Höpner, M. (2006) 'The Political Paradox of Finance Capitalism: Interests, Preferences, and Center-Left Party Politics in Corporate Governance Reform', Politics and Society, 34, 463-502.

Conyon, M. J. (1994) 'Tenure and Contracts: The Experience of UK CEOs', Personnel Review, 23, $25-33$.

Conyon, M. J. and Schwalbach, J. (2000) 'Executive Compensation: Evidence from the UK and Germany', Long Range Planning, 33, 504-526.

Cook, J. and Deakin, S. (1999) 'Stakeholding and Corporate Governance: Theory and Evidence on Economic Performance', Working Paper, Cambridge, ESCR Centre for Business Research, University of Cambridge.

Culpepper, P. (2005) 'Institutional Change in Contemporary Capitalism: Coordinated Financial Systems since 1990', World Politics, 57, 173-199.

Culpepper, P. (2011) Quiet Politics and Business Power: Corporate Control in Europe and Japan, New York, Cambridge University Press.

Davies, R., Richardson, P., Katinaite, V. and Manning, M. (2010) 'Evolution of the UK Banking System', Bank of England Quarterly Bulletin, 50, 321-332.

Dawnay, I. (1991, April 26) 'Labour and City Capitalise on Compromise', Financial Times, London, p. 13.

de Jong, H. W. (1996) 'European Capitalism between Freedom and Social Justice'. In Bratton, W., MacCahery, J. A., Picciotto, S. and Scott, C. (eds) International Regulatory Competition and Coordination, Oxford, Clarendon Press, p. 538.

Deutschmann, C. (2011) 'Limits to Financialization', European Journal of Sociology, 52, 347-389.

Engelen, E. and Konings, M. (2010) 'Financial Capitalism Resurgent: Comparative Institutionalism and the Challenges of Financialization'. In Morgan, G., Campbell, J., Crouch, C., Pedersen, O. K. and Whitley, R. (eds) Oxford Handbook of Comparative Institutional Analysis, Oxford, Oxford University Press, pp. 601-624.

Epstein, G. A. (2005) Financialization and the World Economy, Cheltenham, Edward Elgar.

Erturk, I., Froud, J., Johal, S. and Williams, K. (2005) 'Pay for Corporate Performance or Pay as Social Division? Rethinking the Problem of Top Management Pay in Giant Corporations', Competition \& Change, 9, 49-74.

Fligstein, N. (1993) The Transformation of Corporate Control, Cambridge, MA, Harvard University Press.

Folkman, P., Froud, J., Johal, S. and Williams, K. (2007) 'Working for Themselves? Capital Market Intermediaries and Present Day Capitalism', Business History, 49, 552-572.

Franks, J., Mayer, C. and Rossi, S. (2005) 'Spending Less Time with the Family: The Decline of Family Ownership in the United Kingdom'. In Morck, R. K. (ed) A History of Corporate Governance around the World, Chicago, NBER, pp. 581-607.

Frieden, J. (1999) 'Actors and Preferences in International Relations'. In Lake, D. A. and Powell, R. (eds) Strategic Choice and International Relations, Princeton, NJ, Princeton University Press, pp. $40-76$.

Gourevitch, P. and Shinn, J. (2005) Political Power and Corporate Control: The New Global Politics of Corporate Governance, Princeton, NJ, Princeton University Press.

Hall, P. (2010) 'Politics as a Process Structured in Space and Time', Annual Meeting of the American Political Science Association, Washington, DC, September 4.

Higgins, D. and Thexton, R. (2014) 'The UK Takeover Code', BVCA Legal \& Technical Bulletin, April, 10-12.

Hirsch, P. (1986) 'From Ambushes to Golden Parachutes: Corporate Takeovers as an Instance of Cultural Framing and Institutional Integration', American Journal of Sociology, 91, 800-837. 
Höpner, M. and Jackson, G. (2006) 'Revisiting the Mannesmann Takeover: How Markets for Corporate Control Emerge', European Management Review, 3, 142-155.

Hotten, R. and Conway, E. (2006, February 11) 'Invasion of the Company Snatchers', Daily Telegraph, London, p. 33.

Howard, A. (2005) The Governance of Flexibility: Contemporary Politics and the British Company, Ph.D. thesis, George Washington University.

Jackson, G. and Miyajima, H. (2008) 'A Comparison of Mergers and Acquisitions in Japan, Europe and the United States'. In Strange, R. and Jackson, G. (eds) Corporate Governance and International Business: Strategy, Performance and Institutional Change, Basingstoke, Palgrave MacMillan.

Jackson, G. and Vitols, S. (2001) 'Between Financial Commitment, Market Liquidity and Corporate Governance: Occupational Pensions in Britian, Germany, Japan and the USA'. In Ebbinghaus, B. and Manow, P. (eds) Comparing Welfare Capitalism, London, Routledge, pp. 171-189.

Jacobs, A. M. and Weaver, R. K. (2014) 'When Policies Undo Themselves: Self-Undermining Feedback as a Source of Policy Change', Governance, doi: 10.1111/gove.12101.

Johnston, A. (1980) The City Takeover Code, Oxford, Oxford University Press.

Johnston, A. (2007) 'Takeover Regulation: Historical and Theoretical Perspectives on the City Code', Cambridge Law Journal, 66, 422.

Kelly, G., Kelly, D. and Gamble, A. (1997) Stakeholder Capitalism, London, Macmillan.

Kirchfeld, A. and Matthew, C. (2013, September 13) 'Bankers Chafe under U.K. Takeover Rules', Bloomberg News.

Krippner, G. R. (2011) Capitalizing on Crisis, Cambridge, MA, Harvard University Press.

La Porta, R., Lopez-de-Silanes, F., Shleifer, A. and Vishny, R. (2000) 'Investor Protection and Corporate Governance', Journal of Financial Economics, 58, 3-27.

Lapavitsas, C. (2011) 'Theorizing Financialization', Work, Employment \& Society, 25, 611-626.

Leadbeater, C. (1990, October 25) 'Lilley Warns of Dangers in Deal-Making Culture', Financial Times, London, p. 8.

Lin, K.-H. and Tomaskovic-Devey, D. (2013) 'Financialization and Us Income Inequality, 197020081', American Journal of Sociology, 118, 1284-1329.

Maguire, K. (2001, May 30) 'Blair Pledge to Make Big Takeovers Easier', The Guardian, London, p. 16.

Mahoney, J. and Thelen, K. (2010) 'A Theory of Gradual Institutional Change'. In Mahoney, J. and Thelen, K. (eds) Explaining Institutional Change: Ambiguity, Agency, and Power, New York, Cambridge University Press, pp. 1-37.

McCarthy, M. A. (2014) 'Turning Labor into Capital: Pension Funds and the Corporate Control of Finance', Politics \& Society, 42, 455-487.

McDonough, T. (2005, November 16) 'Firms Clamour to Buy up Britain', Daily Post (North Wales), pp. 8-9.

Morgan, G. (2012) 'Supporting the City: Economic Patriotism in Financial Markets', Journal of European Public Policy, 19, 373-387.

Mueller, D. C. (2012) 'Mergers and the Market for Corporate Control'. In Mueller, D. C. (ed) Oxford Handbook of Capitalism, Oxford, Oxford University Press, pp. 426-460.

Nölke, A. (2014) 'Measuring Financialisation: A Prolegomena', 26th Annual Meeting of the Society for the Advancement of Socio-Economics (SASE), Chicago, July 9-12.

Oppermann, K. and de Vries, C. (2011) 'Analyzing Issue Salience in International Politics: Theoretical Foundations and Methodological Approaches'. In Oppermann, K. and Viehrig, H. (eds) Issue Salience in International Politics, Abingdon, Routledge, pp. 3-20.

Pagliari, S. (2013) 'Public Salience and International Financial Regulation. Explaining the International Regulation of OTC Derivatives, Rating Agencies, and Hedge Funds', Ph.D. thesis, University of Waterloo. 
Panel on Takeovers and Mergers, 1969-2010: Annual Reports. www.thetakeoverpanel.org.uk/ statements/reports.

Patrone, M. R. (2011) 'Sour Chocolate: The Uk Takeover Panel's Improper Reaction to Kraft's Acquisition of Cadbury', BYU International Law and Management Review, 8, 63-86.

Pendleton, A. and Gospel, H. (2005) 'Markets and Relationships: Finance, Governance, and Labour in the United Kingdom'. In Gospel, H. and Pendleton, A. (eds) Corporate Governance and Labour Management, Oxford, Oxford University Press, pp. 59-83.

Pierson, P. (1993) 'When Effect Becomes Cause: Policy Feedback and Political Change', World Politics, 45, 595-628.

Pierson, P. (1994) Dismantling the Welfare State? Reagan, Thatcher, and the Politics of Retrenchment, Cambridge, Cambridge University Press.

Pound, J. (1993) 'The Rise of the Political Model of Corporate Governance and Corporate Control', NYU Law Review, 68, 1003.

Riddell, P. (1988a, May 28) 'Labour Widens the Takeover Debate', Financial Times, London, p. 5.

Riddell, P. (1988b, May 16) 'Ministers Defend Takeover Policy', Financial Times, London, p. 1.

Roberts, R. (1992) 'Regulatory Responses to the Rise of the Market for Corporate Control in Britain in the 1950s', Business History, 34, 183-200.

Seely, A. (2014) 'Takeovers: The Public Interest Test' Standard Note SN05374, House of Commons Library, London, England, p. 25.

Sewell, W. (2008) 'The Temporalities of Capitalism', Socio-Economic Review, 6, 517-537.

Skocpol, T. (1995) Protecting Soldiers and Mothers, Cambridge, MA, Harvard University Press.

Streeck, W. (2009) Re-Forming Capitalism: Institutional Change in the German Political Economy, Oxford, Oxford University Press.

Streeck, W. (2011) 'Taking Capitalism Seriously: Towards an Institutionalist Approach to Contemporary Political Economy', Socio-Economic Review, 9, 137-167.

Streeck, W. and Höpner, M. (2003) 'Einleitung'. In Streeck, W. and Höpner, M. (eds) Alle Macht dem Markt? Fallstudien zur Abwicklung der Deutschland AG, Frankfurt, Campus, pp. 7-59.

Streeck, W. and Thelen, K. (2005) Beyond Continuity: Institutional Change in Advanced Political Economies, Oxford, Oxford University Press.

Sudarsanam, S. (2003) Creating Value From Mergers and Acquisitions: The Challenges, Harlow, Pearson.

Taylor, R. (2000, June 8) 'Tuc Fears Dilution of Business Reforms', Financial Times, London, p. 6.

Thompson, S. (2005) 'The Impact of Corporate Governance Reforms on the Remuneration of Executives in the UK', Corporate Governance, 13, 19-25.

van der Zwan, N. (2011) 'Contentious Capital the Politics of Pension Investment in the United States and Germany, 1974-2003', Ph.D. thesis, New School of Social Research.

van der Zwan, N. (2014) 'Making Sense of Financialization', Socio-Economic Review, 12, 99-129.

von Thadden, E.-L. (1990) 'On the Efficiency of the Market for Corporate Control', Kyklos, 43, 635-658.

Wachman, R. (2009, September 20) 'Cadbury Has Plenty to Fear from Kraft', Observer, p. 6.

Wagstyl, S. and Rice, R. (1997, February 14) 'Competition Policy Facing Radical Reform under Labour', Financial Times, London, p. 10.

Walker, J. and Griffin, J. (2010, January 22) 'MP_“Just End the Whingeing”, Birmingham Evening Mail, p. 5.

White, A. (2012) 'Reassessing the Rationales for the Takeover Bids Directive's Board Neutrality Rule', European Business Law Review, 5, 789-807.

Wiggins, J. (2010, March 12) 'The Inside Story of the Cadbury Takeover', Financial Times Magazine.

Wincott, H. (1959, July 7) 'What to Do About Bids', Financial Times, London, p. 6. 